\title{
EMPLOYEE PERFORMANCE IMPROVEMENT THROUGH STRENGTHENING MOTIVATION AND WORK DISCIPLINE (Case at PT. Sarana Yang Maju in Palembang city)
}

\author{
Susi Handayani \\ Universitas Indo Global Mandiri, Palembang, Sumatera Selatan \\ susi@uigm.ac.id
}

\begin{abstract}
ABSTRACK
Susi Handayani conducted research aimed at knowing whether there was an influence of Work Motivation and Discipline on Employee Performance at PT. Advanced Facilities in the city of Palembang. Quantitative method is the approach used in this study, in this study sampling using the slovin technique with an error of $10 \%$ so that 54 respondents were obtained. After being tested partially, it was stated that there was a positive and significant influence between the motivational variables on the performance of the employees of PT. Advanced Facilities in the city of Palembang, this is based on the results of the $t$-test obtained by the value of $t_{\text {count }}>t_{\text {table }}(2.586>1.674)$ and a significance value of $0.013<0.05$. The test results partially state that there is a positive and significant influence between work discipline variables on employee performance, which is based on the results of the t-test obtained by the value of $t_{\text {count }}>t_{\text {table }}(2,959<1.674)$ and a significance value of $0.005<0.05$. From the results of the discussions that have been carried out in this study, the results of the multiple regression analysis of the equations obtained are $Y=2.071+0.406 X_{1}+0.515 X_{2}$. In conclusion, the variable regression coefficients are 0.506 and 0.515 depending on the implications of the motivational and work discipline variables that have a positive effect in the direction of the employee performance variable.
\end{abstract}

\section{Keywords: Motivation, Work Discipline, Employee Performance}

\section{PENDAHULUAN}

\section{A. Latar Belakang Penelitian}

Kegiatan suatu perusahaan sangat ditentukan dengan keberadaran sumber daya manusia (SDM) sebagai penggerak utama. SDM sebagai salah satu pemegang peranan penting keberhasilan perusahaan atau organisasi, juga sebagai penentu jalannya suatu organisasi sehingga perlu mendapatkan perhatian dari pimpinan. SDM atau karyawan dalam suatu perusahaan diharapkan mampu, cakap dan terampil serta memiliki keinginan serta berupaya mencapai hasil kerja secara maksimal.

Karyawan dengan tingkat semangat kerja memuaskan diharapkan dapat mendorong keberhasilan perusahaan. Saat ini banyak karyawan dalam suatu perusahaan memiliki tingkat kemampuan, ketrampilan sesuai dengan harapan perusahaan, namun yang sering terjadi tidak diiringi dengan semangat tinggi dalam menyalesaikan pekerjaan berakibat pada kinerja yang tidak sesuai harapan. Tingkat pencapaian atau hasil kerja seseorang dalam menyelesaikan masing-masing tanggungjawabnya sesuai dengan sasaran yang telah ditetapkan dikatakan sebagai kinerja. Motivasi diharapkan dapat selalu mengaktifkan serta mengarahkan tingkah laku seseorang pada suatu sasaran tertentu.

Jika seorang karyawan bahagia dalam menyelesaikan pekerjaannya, dapat dikatakan bahwa karyawan tersebut memiliki motivasi dan disiplin tinggi, dikarenakan Moekijat juga berargumen bahwa adanya hubungan erat antara motivasi dan disiplin kerja. Adanya tanggungjawab yang besar dimiliki seorang karyawan terhadap tugas yang bebankan merupakan cerminan dari disiplin karyawan tersebut baik, sehingga diharapkan tercapainya efektivitas kerja secara maksimal.

Dengan adanya peraturan yang telah ditetapkan diharapkan mampu memberikan bimbingan melalui penyuluhan yang diberikan kepada karyawan sehingga terciptanya tata tertib yang baik dan diharapkan efisien dan efektivitas kerja karyawan dapat meningkat. Keberhasilan suatu perusahaan dapat dilihat pada kemampauannya meningkatkan kinerja perusahaan dimana dapat dicapai melalui kinerja karyawan yang baik. 
PT. Sarana Yang Maju memiliki tugas pokok yaitu membantu masyarakat dalam hal pembayaran pajak kendaraan bermotor, dikaitkan dengan adanya kegiatan suatu perusahaan mencapai tujuan tertentu. Gambaran yang ada tidak terlepas karena adanya beberapa faktor yang turut mempengaruhi yaitu: motivasi, disiplin, dan sebagainya.

Dengan adanya faktor yang turut memepengaruhi diharapkan dapat menjadi aspek penting sebagai upaya merangsang tumbuhnya kinerja karyawan. Selanjutnya timbul pemikiran, bagaimana kedua faktor utama dalam penelitian ini dapat saling kerkesinambungan sehingga mempengaruhi kinerja karyawan. Selanjutnya dalam usaha melaksanakan kajian mendalam berhubungan dengan peningkatan kinerja karyawan, terlebih dahulu ditampilkan mengenai kinerja karyawan PT. Sarana Yang Maju selama dua tahun terakhir dalam tabel berikut:

Tabel 1: Kinerja Karyawan PT. Sarana Yang Maju

\begin{tabular}{|c|l|c|c|c|c|c|c|}
\hline \multirow{2}{*}{ No } & \multirow{2}{*}{$\begin{array}{c}\text { Komponen } \\
\text { Kinerja }\end{array}$} & \multicolumn{6}{|c|}{ TAHUN } \\
\cline { 3 - 8 } & & \multicolumn{3}{|c|}{2019} & \multicolumn{3}{c|}{2020} \\
\cline { 3 - 8 } & & Tujuan & Jangkauan & $\%$ & Tujuan & Jangkauan & $\%$ \\
\hline 1. & Kuantitas & 176 & 150 & $85 \%$ & 145 & 120 & $83 \%$ \\
\hline 2. & Kulitas & 172 & 135 & $78 \%$ & 147 & 112 & $76 \%$ \\
\hline 3. & Tanggungjawab & 160 & 125 & $78 \%$ & 168 & 123 & $73 \%$ \\
\hline 4. & $\begin{array}{l}\text { Pelaksanaan } \\
\text { Tugas }\end{array}$ & 156 & 122 & $78 \%$ & 160 & 125 & $78 \%$ \\
\hline \multicolumn{3}{|c|}{ TOTAL } & & $80 \%$ & & & $76 \%$ \\
\hline
\end{tabular}

Sumber: PT. Sarana Yang Maju, 2020

Tabel 1 diatas memperlihatkan bahwa terjadi fluktuatif naik turun pada setiap komponen kinerja karyawan untuk dua tahun terakhir. Setelah dilakukan observasi dan wawancara penulis dapat menyimpulkan bahwa penyebab utama terjadinya penurunan kinerja karyawan pada setiap komponen adalah motivasi dan disiplin kerja.

\section{A. Rumusan Masalah}

1. Apakah motivasi berpengaruh terhadap kinerja karyawan PT. Sarana Yang Maju.

2. Apakah disiplin kerja berpengaruh terhadap kinerja karyawan PT. Sarana Yang Maju.

3. Apakah motivasi dan disiplin kerja berpengaruh terhadap kinerja karyawan PT. Sarana Yang Maju.

B. Tujuan Penelitian

Dengan didasarkan rumusan masalah, sehingga tujuan penelitian yang peneliti lakukan:

1. Sebagai usaha PT. Sarana Yang Maju mengetahui apakah motivasi berpengaruh terhadap kinerja karyawan.

2. Sebagai usaha PT. Sarana Yang Maju mengetahui apakah disiplin kerja berpengaruh terhadap kinerja karyawan.

3. Sebagai usaha PT. Sarana Yang Maju mengetahui apakah motivasi dan disiplin kerja berpengaruh terhadap kinerja karyawan.

\section{TINJAUAN PUSTAKA dan PENGEMBANGAN HIPOTESIS}

A. Hakekat Kinerja

Kinerja dalam suatu perusahaan adalah jawaban keberhasilan dari suatu tujuan yang telah ditetapkan. Yusniar Lubis, Bambang Hermanto dan Emron Edison (2019:26) that performance is the result of aprocess with reference to and measured over a certain period based on the provisions, standards and agreements that have been previously set.

Kinerja karyawan melakukan sesuatu kegiatan serta menyempurnakannya sesuai dengan tanggungjawabnya untuk mendapatkan hasil sesuai harapan. Sementara itu Hubeis dan Mangkuprawira (2007:153) menyatakan kinerja adalah hasil dari pekerjaan dilakukan secara berencana pada waktu serta tempat perusahaan karyawan tersebut berada. Sandy (2015:11) mengemukakan kinerja adalah suatu prestasi yang dicapai oleh karyawan pada saat menjalankan pekerjaan yang diberikan. Sementara itu 


\section{Seminar Ilmiah Sistem Informasi Manajemen dan Akuntansi (SISIMA) 2021}

Vol 1, No 1, 2021, 21-31

https://doi.org/10.35912/sisima.v1i1.3

Ilyas (2001:66) mengemukakan kinerja merupakan penampilan hasil karyawa personel dalam suatu organisasi

Kinerja diartikan sebagai sesuatu yang dihasilkan seseorang dari pekerjaanya guna mencapai tujuan organisasi pada kurun waktu tertentu (Tika, 2006:121). Menurut definisi para ahli diatas penulis mensintesiskan kinerja adalah hasil kerja yang dilakukan seseorang agar tercapai tujuan dan meminimalisir kerugian dalam suatu organisasi.

\section{B. Motivasi}

Kondisi suatu energi diharapkan dapat menggerakkan diri akryawan secara terarah atau tertuju dalam upaya mencapai tujuan perusahaan dikatakan sebagai motivasi (Mangkunegara, 2002:61). Uno (2007) mengemukan bahwa motivasi merupakan dorongan secara internal dan eksternal dalam diri seseorang diindikasikan dengan adanya hasrat, minat, dorongan disertai kebutuhan, harapan, cita-cita, penghargaan dan penghormatan. Mc. Donald (Sardiman, 2007:73) mengemukakan motivasi sebagai perubahan energi dalam diri seseorang ditandai dengan adanya feeling serta didahului dengan tanggapan terhadap tujuan tersebut.

Mangkunegaran (2016:61) mengemukakan bahwa motivasi sebagai suatu kondisi mendorong karyawan secara terarah mencapai tujuan perusahaan. Morgan et al (Marwansyah dan Mukaram, 2002:151) mengemukakan motivasi adalah kekuatan mengendalikan disertai menggerakkan seseorang melakukan tindakan mengarah pada tujuan tertentu. Motivasi adalah hasil interaksi seseorang terhadap situasi yang dihadapinya (Siagian, 2004). Sementara itu Syahyuti (2010:93) mengemukakan pendapatnya bahwa motivasi merupakan pemberian daya pendorong bagi seseorang untuk melakukan pekerjaan dengan baik.

Penulis mencoba untuk mensintesiskan motivasi adalah suatu rangsangan sehingga seseorang dengan sukarela dan tidak ada paksaan melakukan pekerjaan untuk mendapatkan hasil maksimal.

\section{Disiplin Kerja}

Suatu modal yang dibutuhkan dalam usaha penyelesaian rencana kerjanya untuk pencapaian tujuan perusahaan serta suatu faktor terpenting dari adanya pemanfaatan sejumlah individu dalam rangka pencapaian tujuan adalah disiplin kerja. Disiplin adalah cerminan terpenting dari besarnya rasa tanggungjawab seorang karyawan terhadap tugas-tugas yang dibebankan. Sebagai alat yang dapat dipakai manajer melakukan komunikasi kepada karyawan sehingga mau mengganti suatu tingkah laku disertai berbagai upaya dalam usaha meningkatkan kesadaran serta kesediaan seseorang mentaati semua peraturan perusahaan dan norma-norma sosial yang berlaku disebut dengan disiplin kerja (Rival, 2004, h:444).

Sementara itu Stuart Emmel (2001) mengemukakan disiplin sebagai suatu sistem aturan untuk melakukan pengendalian perilaku. Larterner (Prihantoro, 2012) mengemukakan disiplin kerja bila karyawan datang tepat waktu, mempergunakan alat kantor dengan rasa tanggungjawab, hasil pekerjaan memuaskan serta bekerja dengan semangat tinggi.

Roffi (2012) mengemukakan disiplin kerja sangat dibutuhkan karena apa yang menjadi tujuan organisasi akan sukar dicapai bila tidak ada disiplin kerja. Dari definisi yang telah di kemukakan, penulis mencoba untuk mensintesiskan bahwa disiplin kerja adalah perbuatan sesuai dengan peraturan sekolah secara tertulis ataupun tidak.

\section{PENGEMBANGAN HIPOTESIS}

Pengembangan Hipotesa dilakukan peneliti menggunakan sejumlah penelitian terdahulu, bertujuan untuk mendapatkan perbandingan serta acuan. Peneliti menggunakan penelitian terdahulu sebagai upaya menghindari adanya kesamaan penelitian yang sedang dilakukan:

1. Nita Nilamsari (2014) judul penelitian Pengaruh Motivasi Kerja terhadap Kinerja Karyawan serta dampaknya pada kualitas pelayanan Housekeeping Department di Padma Hotel 26 Bandung. Hasil dari penelitian yang telah dilakukan dinyatakan bahwa motivasi kerja mempengaruhi kinerja sebesar 72,9\%. Jentot Tugiyono (2019) judul Pengaruh motivasi kerja terhadap kinerja karyawan LPK Pramidia Bandung. Hasil penelitian dinyatakan adanya pengaruh motivasi terhadap kinerja 
karyawan secara signifikan. Tri Hardjono (2013) judul penelitian Analisis Pengaruh Motivasi Kerja dan Kemampuan Kerja Terhadap PNS. Hasil penelitian diperoleh adanya pengaruh perubahan motivasi dan kemampuan kerja terhadap perubahan kinerja pegawai. Dari uraian yang telah dikemukakan dirumuskan hipotesisnya:

\section{$\mathbf{H}_{1}$ : Diduga terdapat pengaruh motivasi terhadap Kinerja Karyawan.}

2. Azwar (2015) judul penelitian Pengaruh Disiplin Kerja Terhadap Kinerja Karyawan Hotel Grand Inna Muara Padang. Hasil penelitian dinyatakan bahwa adanya pengaruh signifikan antara disiplin kerja terhadap kinerja karyawan Hotel Grand Inna Muara Padang sebesar 6,8\%. Elvi Lastriani (2014) penelitian berjudul Pengaruh Disiplin Terhadap Kinerja Anggota Pada Satlantas Polresta Pekanbaru. Hasil penelitian Bahwa Disiplin berpengaruh terhadap peningkatan kinerja anggota satlantas Polresta Pekanbaru. Galih Rakawisi (2014), judul penelitian Pengaruh Motivasi, Kepuasan Kerja dan Disiplin Kerja Terhadap Kinerja Pegawai.Hasil penelitian Disiplin Kerja berpengaruh negatif signifikan terhadap kinerja pegawai. Dari uraian yang telah dikemukakan dirumuskan hipotesisnya:

\section{$\mathrm{H}_{2}$ : Diduga terdapat pengaruh disiplin kerja terhadap kinerja karyawan}

3. M. Holil dan Agus Sriyanto (2010), Judul penelitian Pengaruh Motivasi dan Disiplin Kerja Terhadap Kinerja Pegawai (Studi Kasus pada Kantor Pelayanan Pajak BUMN). Hasil penelitian setelah dilakukan olah data maka dinyatakan Motivasi dan disiplin kerja secara simultan berpengaruh terhadap kinerja karyawan. Yoga Arsyenda (2013), judul penelitian Pengaruh Motivasi kerja dan Disiplin Kerja terhadap Kinerja PNS BAPPEDA Kota Malang. Hasil penelitian menyatakan Disiplin kerja sangat berpengaruh terhadap kinerja PNS BAPPEDA Kota Malang. Natalia Susanto (2019) judul penelitian Pengaruh Motivasi, Kepuasan Kerja dan Disiplin Terhadap Kinerja Karyawan Divisi Penjualan PT. Rembaka. Hasil penelitian dinyatakan Motivasi, dan Disiplin secara simultan berpengaruh terhadap kinerja. Ivonne A. S. Sajangbati (2013) judul penelitian Motivasi, Disiplin dan Kepuasan Pengaruhnya Terhadap Kinerja Pegawai PT. Pos Indonesia (Persero) Cabang Bitung. Hasil penelitian dinyatakan bahwa diduga Motivasi, Disiplin dan Kepuasan berpengaruh terhadap kinerja pegawai. Dari uraian yang telah dikemukakan dirumuskan hipotesisnya

$\mathrm{H}_{3}$ : Diduga terdapat pengaruh motivasi dan disiplin kerja terhadap kinerja karyawan.

\section{METODE PENELITIAN}

\section{A. Populasi}

Widiyanto (2010:5) menyatakan populasi adalah kelompok atau kumpulan objek selanjutnya digeneralisasikan, berjumlah 116 orang

B. Sampel

Sampel diharapkan dapat mewakili keseluruhan yang diamati. Untuk mendukung penelitian yang penulis lakukan digunakan sampel berjumlah 54 orang.

C. Jenis Penelitian.

Menggunakan jenis Penelitian kualitatif, dimana berangkat dari paradigma fenomenologi menggunakan analisis kualitatif dengan hasil akhir berbentuk deskripsi

D. Metode analisis data

Merupakan komponen penting dalam proses data analysis dimana data yang telah dikumpulkan dilakukan pemrosesan untuk dihasilkan suatu kesimpulan dalam hal pengambilan keputusan. Pada penelitian ini penulis melakukan uji instrumen, uji asumsi klasik, regresi linier berganda, koefisien korelasi, koefisien determinasi juga dilakukan uji hipotesis sebagai upaya melakukan analisis data.

\section{HASIL DAN PEMBAHASAN}

1. Uji Verifikatif

Dimaksudkan guna mengetahui besaran pengaruh variabel independen terhadap variabel dependen serta melakukan analisis signifikansi dari pengaruh tersebut. 


\section{Seminar Ilmiah Sistem Informasi Manajemen dan Akuntansi (SISIMA) 2021}

a. Uji regresi linier berganda

Dilakukannya uji regresi linier berganda untuk mengetahui besaran pengaruh variabel motivasi $\left(\mathrm{X}_{1}\right)$ serta disiplin $\operatorname{kerja}\left(\mathrm{X}_{2}\right)$ terhadap kinerja karyawan $(\mathrm{Y})$ dengan persamaan $\mathrm{Y}=$ $a+b_{1} X_{1}+b_{2} X_{2}$ dihitung menggunakan software SPSS versi 23 dapat dilihat berikut:

Tabel 2: Regresi linier berganda variabel motivasi dan disiplin kerja terhadap kinerja karyawan

\section{Coefficients ${ }^{\mathrm{a}}$}

\begin{tabular}{|c|c|c|c|c|c|}
\hline \multirow[b]{2}{*}{ Model } & \multicolumn{2}{|c|}{$\begin{array}{l}\text { Unstandardized } \\
\text { Coefficients }\end{array}$} & \multirow{2}{*}{$\begin{array}{l}\text { Standardized } \\
\text { Coefficients } \\
\text { Beta }\end{array}$} & \multirow{2}{*}{ 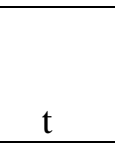 } & \multirow[b]{2}{*}{ Sig. } \\
\hline & B & Std. Error & & & \\
\hline (Consta & 2.071 & .949 & & 2.183 & .034 \\
\hline MOT & .406 & .157 & .442 & 2.586 & .013 \\
\hline DISIPLIN KERJA & .515 & .174 & 506 & 2959 & .005 \\
\hline
\end{tabular}

a. Dependent Variable: KINERJA KARYAWAN

Sumber: Data diolah 2021

Dari hasil analisis regresi yang telah dilakukan seperti tercermin pada tabel 2 diperoleh persamaan regresi yaitu $\mathrm{Y}=2,071+0,406 \mathrm{X}_{1}+0,515 \mathrm{X}_{2}$ dan interpretasi dari persamaan diatas dinyatakan koefisien variabel motivasi $\left(\mathrm{X}_{1}\right)$ 0,406 dan variabel disiplin $\operatorname{kerja}\left(\mathrm{X}_{2}\right)$ 0,515 bearti implikasikan bahwa motivasi dan disiplin kerja secara bersama-sama berpengaruh positif dan signifikan dengan variabel kinerja karyawan $(\mathrm{Y})$

b. Analisis koefisien korelasi

Dilakukannya analisis koefisien korelasi bertujuan untuk mengetahui tingkat kekuatan pengaruh serta hubungan dari variabel independen terhadap variabel dependen secara parsial ataupun simultan. Analisis koefisien korelasi dihitung menggunakan software SPSS versi 23 seperti terlihat pada tabel berikut:

Tabel 3: Hasil uji analisis koefisien korelasi

Correlations

\begin{tabular}{|c|c|c|c|}
\hline & Motivasi & $\begin{array}{l}\text { Disiplin } \\
\text { Kerja } \\
\end{array}$ & $\begin{array}{l}\text { Kinerja } \\
\text { Karyawan }\end{array}$ \\
\hline $\begin{array}{cl}\text { Motivasi } & \text { Pearson Correlation } \\
& \text { Sig. (2-tailed) } \\
& \text { N }\end{array}$ & $\begin{array}{r}1 \\
54\end{array}$ & $\begin{array}{r}.959^{* *} \\
.000 \\
54\end{array}$ & $\begin{array}{r}.928^{* *} \\
.000 \\
54\end{array}$ \\
\hline $\begin{array}{ll}\text { Disiplin } & \text { Pearson Correlation } \\
\text { Kerja } & \text { Sig. (2-tailed) } \\
& \text { N }\end{array}$ & $\begin{array}{r}.959^{* *} \\
.000 \\
54\end{array}$ & 1 & $\begin{array}{r}.930^{* *} \\
.000 \\
54\end{array}$ \\
\hline $\begin{array}{l}\text { Kinerja Pearson Correlation } \\
\text { Karyawan Sig. (2-tailed) } \\
\text { N }\end{array}$ & $\begin{array}{r}.928^{* *} \\
.000 \\
54\end{array}$ & $\begin{array}{r}.930^{* *} \\
.000 \\
54\end{array}$ & 1 \\
\hline
\end{tabular}

** Correlation is significant at the 0.01 level (2-tailed)

Sumber: Data diolah 2021

Dari hasil analisis koefisien korelasi pada tabel 3 dimana nilai korelasi dari motivasi dan disiplin kerja 0,959 atau 95,9\% dan nilai korelasi dari disiplin kerja terhadap kinerja karyawan sebesar 0,930 atau 93,0\% dikarenakan koefisien mendekati 1 sehingga disimpulka antara disiplin kerja dan kinerja karyawan memiliki hubungan kuat. Nilai korelasi motivasi terhadap kinerja karyawan sebesar 0,928 atau $92 \%$ menunjukkan hubungan positif yang bearti jika motivasi meningkat maka kinerja karyawan 
juga akan mengalami peningkatan, begitu juga dengan disiplin kerja jika mengalami peningkatan maka kinerja karyawan juga akan meningkat.

c. Analisis koefisien determinasi

Dilakukannya analisis koefisien determinasi bertujuan guna mengetahui presentase dari pengaruh variabel independen terhadap variabel dependen baik secara parsial ataupun secara simultan dengan menggunakan rumus $\mathrm{KD}=\mathrm{R}^{2} \mathrm{x} 100 \%$ dan menggunakan software SPSS versi 23 sehingga diperoleh hasil seperti tercermin pada tabel berikut:

Tabel 4. Hasil Uji Analisis Koefisien Determinasi

\begin{tabular}{|c|c|c|c|c|}
\hline & \multicolumn{4}{|c|}{ Model Summary } \\
\hline Model & $\mathrm{R}$ & R Square & Adjusted R Square & $\begin{array}{l}\text { Std. Error of the } \\
\text { Estimate }\end{array}$ \\
\hline 1 & $.939^{\mathrm{a}}$ & .881 & .876 & 2.199 \\
\hline
\end{tabular}

a. Predictors: (Constant), MOTIVASI, DISIPLIN KERJA

Sumber; Data diolah 2021

Dari hasil perhitungan analisis koefisien determinasi seperti tercermin pada tabel 4 diperoleh nilai koefisien determinasi(R-Square) sebesar 0,876. Sehingga disimpulkan motivasi $\left(X_{1}\right)$, disiplin kerja $\left(X_{2}\right)$ secara bersama-sama memiliki pengaruh sebesar 87,6\% terhadap kinerja karyawan(Y) dan 12,6\% dipengaruhi faktor lain yang tidak diteliti dalam penelitian ini.

2. Uji Signifikansi

a. Uji t

Uji $t(t-t e s t)$ biasa disebut dengan uji parsial, digunakan untuk pengujian hipotesis menggunakan analisis linier sederhana. Pengujian hipotesis dilakukan untuk menguji secara statistik(uji t) apakah rumusan hipotesis yang telah dibuat diterima atau ditolak. Penulis melakukan Pengujian pada penelitian ini secara parsial antara variabel independen terhadap variabel dependen menggunakan kriteria:

1. Jika Sig $<0,05$ atau $t_{\text {hitung }}>\mathrm{t}_{\text {tabel }}$ dinyatakan ada pengaruh signifikan, maka Ho ditolak dan Ha diterima.

2. Jika Sig $>0,05$ atau $t_{\text {hitung }}<t_{\text {tabel }}$ dinyatakan tidak ada pengaruh signifikan, maka Ho diterima dan Ha ditolak.

3. $t_{\text {tabel }}$ dengan tingkat keyakinan $90 \%$ serta tingkat kesalahan $(\alpha) 10 \%=0.10$ serta tingkat kebebasan $(\mathrm{df})=\mathrm{n}-\mathrm{k}$

$(\mathrm{df})=0.10(54-2)$ yaitu $0.10=52$ maka nilai $\mathrm{t}_{\text {tabel }}=1.674$

Hipotesis pada penelitian ini:

Ho : $\rho 1$ : Motivasi secara parsial tidak berpengaruh signifikan terhadap kinerja karyawan pada PT. Sarana Yang Maju di kota Palembang

$\mathrm{Ha}: \rho 1$ : Motivasi secara parsial berpengaruh signifikan terhadap kinerja karyawan Pada PT. Sarana Yang Maju di kota Palembang

Ho : $\rho 1$ : Disiplin kerja secara parsial tidak berpengaruh signifikan terhadap kinerja karyawan pada PT. Sarana Yang Maju di kota Palembang

$\mathrm{Ha}: \rho 1$ : Disiplin kerja secara parsial berpengaruh signifikan terhadap kinerja karyawan pada PT. Sarana Yang Maju di kota Palembang.

Selanjutnya penulis melakukan pengujian hipotesis dengan menggunakan software SPSS versi 23 sehingga diperoleh hasil:

Tabel 5: Hasil Uji t

Coefficients $^{\mathbf{a}}$

\begin{tabular}{|l|l|l|c|c|c|}
\hline \multirow{2}{*}{ Model } & \multicolumn{2}{|c|}{$\begin{array}{c}\text { Unstandardized } \\
\text { Coefficients }\end{array}$} & $\begin{array}{c}\text { Standardized } \\
\text { Coefficients }\end{array}$ & \multirow{2}{*}{ t } & \multirow{2}{*}{ Sig } \\
\cline { 2 - 4 } & $\mathrm{B}$ & Std. Error & Beta & t \\
\hline
\end{tabular}




\section{Seminar Ilmiah Sistem Informasi Manajemen dan Akuntansi (SISIMA) 2021}

Vol 1, No 1, 2021, 21-31 https://doi.org/10.35912/sisima.v1i1.3

\begin{tabular}{|c|r|r|r|r|l|}
\hline $1 \quad$ (Constant) & 2.071 & .949 & & 2.183 & .034 \\
\hline MOTIVASI & .406 & .157 & .442 & 2.586 & .013 \\
\hline $\begin{array}{c}\text { DISIPLIN } \\
\text { KERJA }\end{array}$ & .515 & .174 & .506 & 2.959 & .005 \\
\hline
\end{tabular}

a. Dependent Variable: KINERJA KARYAWAN

Sumber: Data diolah 2021

Pada tabel 4.4 dapat diketahui bahwa nilai signifikansi pengaruh motivasi $\left(\mathrm{X}_{1}\right)$ terhadap kinerja karyawan(Y) sebesar $0,013<0,05$ dengan nilai $t_{\text {hitung }} 2,586>t_{\text {tabel }} 1,674$ sehingga diperoleh kesimpulan Ho: $\rho 1$ ditolak dan Ha: $\rho 1$ diterima, secara parsial terdapat pengaruh motivasi terhadap kinerja karyawan di kota Palembang. Nilai signifikansi pengaruh disiplin $\operatorname{kerja}\left(\mathrm{X}_{2}\right)$ terhadap kinerja karyawan $(\mathrm{Y})$ sebesar $0,000<0,10$ dengan nilai thitung 2,959 > $t_{\text {tabel }}$ 1,674 sehingga diperoleh kesimpulan Ho: $\rho 1$ ditolak dan Ha: $\rho 1$ diterima, secara parsial terdapat pengaruh disiplin kerja terhadap kinerja karyawan PT. Sarana Yang Maju di kota Palembang.

b. Uji F

Penulis melakukan uji statistik $\mathrm{F}$ (uji simultan) pada penelitian ini guna mengetahui apakah ada pengaruh variabel motivasi $\left(\mathrm{X}_{1}\right)$ dan disiplin $\operatorname{kerja}\left(\mathrm{X}_{2}\right)$ terhadap kinerja $\operatorname{karyawan}(\mathrm{Y})$ menggunakan kriteria:

1. Dikatakan adanya pengaruh signifikan secara simultan antara variabel independen terhadap vaariabel dependen jika Sig $<0,05$ atau $t_{\text {hitung }}>F_{\text {tabel }}$.

2. Dikatakan tidak adanya pengaruh signifikan secara simultan antara variabel independen terhadap variabel dependen jika Sig $>0,05$ atau $t_{\text {hitung }}<\mathrm{F}_{\text {tabel. }}$.

3. $F_{\text {tabel }}$ menggunakan tingkat kenyakinan $90 \%$ serta tingkat kesalahan $(\alpha) 10 \%=0,1$ dan tingkat kebebasan(df) $\mathrm{v}_{1}=\mathrm{k}-1=3-2=2$, dan $\mathrm{v}_{2}=\mathrm{n}-\mathrm{k}=54-2=52$, dengan nilai $\mathrm{F}_{\text {tabel }} 2,41$ sehingga dapat disimpulkan hipotesisnya:

Ho:९3 : Secara simultan tidak adanya pengaruh signifikan dari motivasi dan disiplin kerja terhadap kinerja karyawan PT. Sarana Yang Maju di kota Palembang.

Ha:p3 : Secara simultan terdapat pengaruh signifikan dari motivasi dan disiplin kerja terhadap kinerja karyawan PT. Sarana Yang Maju di kota Palembang.

Selanjutnya penulis melakukan pengujian hipotesis menggunakan software SPSS versi 23 dengan hasil seperti terlihat pada tabel berikut:

Tabel 6: Hasil Uji F

\begin{tabular}{|c|c|c|c|c|c|}
\hline \multicolumn{6}{|c|}{ ANOVA $^{\mathrm{a}}$} \\
\hline Model & Sum of Squares & Df & $\begin{array}{l}\text { Mean } \\
\text { Square }\end{array}$ & $\mathrm{F}$ & Sig \\
\hline 1 Regression & 1822.882 & 2 & 911.441 & 188.498 & $.000^{\mathrm{b}}$ \\
\hline Residual & 246.599 & 51 & 4.835 & & \\
\hline Total & 2069.481 & 53 & & & \\
\hline
\end{tabular}

a. Dependent Variable: KINERJA KARYAWAN

b. Predictors: (Constant), MOTIVASI, DISIPLIN KERJA

Sumber: Data diolah 2021

Pada tabel 6 terlihat bahwa secara simultan motivasi $\left(\mathrm{X}_{1}\right)$ dan disiplin $\operatorname{kerja}\left(\mathrm{X}_{2}\right)$ berpengaruh terhadap kinerja karyawan(Y) di kota Palembang dengan nilai signifikansi sebesar $0,000<0,05$ dan nilai $F_{\text {hitung }} 188.498>F_{\text {tabel }}$ 2,41 dan disimpulkan Ho $: \rho 3$ ditolak dan Ha $: \rho 3$ diterima.

\section{Pembahasan :}


Tujuan dilakukannya penelitian untuk mengetahui pengaruh motivasi dan disiplin kerja terhadap kinerja karyawan PT. Sarana Yang Maju di kota Palembang. Setalah dilakukan pengolahan data pada penelitian ini, selanjutnya penulis akan melakukan pembahasan terhada masing-masing variabel penelitian, seperti tersaji berikut:

\section{Pengaruh Motivasi terhadap Kinerja Karyawan PT. Sarana Yang Maju di Kota Palembang.}

Dari hasil uji yang telah penulis lakukan secara parsial dan simultan terhadap variabel motivasi dengan nilai $t_{\text {hitung }} X_{1}=2,586$ dengan taraf kesalahan 5\% atau dengan nilai signifikansi 0,013< 0,05 diperkuat dengan hasil uji analisis koefisien korelasi sebesar 0,928 atau 92\% berpengaruh signifikan serta memiliki hubungan sangat erat antara motivasi terhadap kinerja karyawan. Dari hasil analisis yang penulis lakukan pada penelitian ini dinyatakan bahwa motivasi memiliki pengaruh positif terhadap kinerja karyawan PT. Sarana Yang Maju di kota Palembang yang dibuktikan dari hasil kuesioner indikator motivasi memiliki skor tertinggi(5). Sehingga penulis dapat memberikan kesimpulan motivasi memiliki pengaruh prositif terhadap kinerja karyawan karena pada pelaksanaan sehari-hari pimpinan selalu diberikan pujian ketika karyawan tersebut memberikan prestasi yang baik sehingga karyawan merasa terdorong dan semangat untuk selalu memberikan prestasi baik dalam bekerja.

\section{Pengaruh Disiplin Kerja terhadap Kinerja Karyawan PT. Sarana Yang Maju di Kota Palembang.}

Dari hasil uji yang telah penulis lakukan secara parsial dan simultan terhadap variabel disiplin kerja dengan nilai $t_{\text {hitung }} \mathrm{X}_{2}=2,959$ dengan taraf kesalahan 5\% atau dengan nilai signifikansi $0,005<$ 0,05 diperkuat dengan hasil uji analisis koefisien korelasi sebesar 0,930 atau 93\% berpengaruh signifikan serta memiliki hubungan sangat erat antara disiplin kerja terhadap kinerja karyawan. Hasil analisis yang penulis lakukan pada penelitian ini diperoleh bahwa disiplin kerja memiliki pengaruh terhadap kinerja karyawan PT. Sarana Yang Maju di kota Palembang hal ini dibuktikan dengan hasil kuesioner indikator disiplin kerja dengan skor(4). Selanjutnya dapat penulis simpulkan disiplin kerja memberikan pengaruh positif terhadap kinerja karyawan.

\section{Pengaruh Motivasi dan Disiplin Kerja terhadap Kinerja Karyawan PT. Sarana Yang Maju di Kota Palembang.}

Dari hasil uji yang telah penulis lakukan secara parsial dan simultan terhadap variabel motivasi $\left(\mathrm{X}_{1}\right)$ dan variabel disiplin $\operatorname{kerja}\left(\mathrm{X}_{2}\right)$, nilai $\mathrm{F}_{\text {hitung }} 188.498>2,41$ tingkat kesalahan 5\% dinyatakan terdapat pengaruh signifikan, Ho: $\rho 3$ ditolak dan Ha: $\rho 3$ diterima hal ini juga diperkuat dengan adanya kontribusi R Square sebesar 0,881 atau $88,1 \%$ berada pada tingkat hubungan sangat kuat, sehingga penulis dapat memberikan kesimpulkan adanya pengaruh positif terhadap kinerja karyawan yang ditimbulkan dari variabel motivasi dan disiplin kerja.

\section{KESIMPULAN}

1. Dari hasil pengujian yang telah dilakukan secara parsial dinyatakan terdapat pengaruh positif dan signifikan antara variabel motivasi terhadap kinerja karyawan, hal ini didasarkan pada hasil uji t yang diperoleh nilai $t_{\text {hitung }}>t_{\text {tabel }}(2,586>1.674)$ dan nilai signifikansi $0,013<0,05$.

2. Dari hasil pengujian yang telah dilakukan secara parsial dinyatakan terdapat pengaruh positif dan signifikan antara variabel disiplin kerja terhadap kinerja karyawan, hal ini didasarkan pada hasil uji t yang diperoleh nilai $t_{\text {hitung }}>t_{\text {tabel }}(2,959<1.674)$ dan nilai signifikansi $0,005<0,05$.

3. Dari hasil pembahasan yang telah penulis lakukan pada penelitian ini, hasil analisis regresi berganda persamaan yang diperoleh $Y=2,071+0,406 X_{1}+0,515 X_{2}$. Kesimpulannya koefisien regresi variabel 0,506 dan 0,515 tergantung implikasi variabel motivasi dan disiplin kerja berpengaruh positif searah dengan variabel kinerja karyawan.

4. $F_{\text {hitung }}>F_{\text {tabel }}(188.498>2,41)$ diperkuat dengan nilai probability signifikan $0,005<0,05$ dapat disimpulkan adanya pengaruh positif serta signifikan variabel motivasi dan disiplin kerja terhadap kinerja karyawan PT. Sarana Yang Maju di kota Palembang secara simultan.

\section{Limitasi dan studi lanjutan}




\section{Seminar Ilmiah Sistem Informasi Manajemen dan Akuntansi (SISIMA) 2021}

Suatu penelitian tidak terlepas dari adanya sejumlah keterbatasan. Penulis menyadari bahwa pada suatu penelitian akan terjadi banyak hambatan serta kelemahan. Kelemahan yang dirasakan penulis perlu diungkapkan dalam bahasa yang sama untuk kesempurnaan penelitian selanjutnya.

1. Dalam rangka peningkatan motivasi, sebaiknya pimpinan perlu mendorong karyawan yang dipimpinnya untuk mau berjalan bersama-sama sehingga tujuan yang telah ditetapkan dapat tercapai.

2. Peningkatan disiplin kerja karyawan di beberapa perusahaan di kota Palembang perlu dilakukan dengan cara pemberian sanksi tegas bagi karyawan yang melakukan pelanggaran terhadap peraturan yang telah ditetapkan.

3. Memberikan kesempatan kepada karyawan untuk melanjutkan pendidikan, memberikan pelatihan, memberikan kesempatan dalam rangka peningkatan karir dan jabatan serta adanya pemberian penghargaan bagi karyawan berprestasi merupakan salah satu cara yang dapat digunakan untuk meningkatkan kinerja karyawan.

4. Bagi peneliti lain, penulis berharap penelitian ini dapat menjadi referensi bagi penelitian selanjutnya yang berkaitan dengan motivasi dan disiplin kerja terhadap kinerja karyawan dengan menambahkan variabel lain seperti lingkungan kerja, etos kerja ataupun variabel lain yang dapat menunjang peningkatan kinerja karyawan.

\section{Ucapan terima kasih}

Alhamdulillah, segala puji hanya milik Allah SWT, berkat rahmat dan berkahnya penulis dapat menyelesaikan artikel ilmiah ini. Artikel ilmiah ini dapat penulis selesaikan dengan baik dan lancar tidak semata-mata hanya usaha penulis sendiri melainkan adanya bantuan tulus dari berbagai pihak, serta ucapan terima kasih juga penulis sampaikan kepada:

1. Dekan Fakultas Ekonomi Universitas Indo Global Mandiri, Ibu Endah Dewi Purnamasari, SE., MM yang telah memberikan kesempatan kepada penulis untuk melakukan penelitian dalam rangka penulis artikel ilmiah.

2. Ketua Program Studi Manajemen Universitas Indo Global Mandiri, Ibu Shafiera Lazuarni. SE., M. Sc yang telah memberikan kesempatan kepada penulis dalam rangka penulisan artikel ilmiah.

3. Kepada Bapak Joni MG selaku pimpinan PT. Sarana Yang Maju terima kasih penulis ucapkan telah memberikan kesempatan kepada penulis untuk melakukan survey guna pengambilan data bagi keperluan penulisan artikel ilmiah.

4. Kepada keluarga besarku yang telah senantiasa memberikan motivasi baik dalam bentuk finansial maupun non finansial sehingga semuanya dapat terlaksana dengan baik.

5. Kepada semua panitia SISIMA 2021 terima kasih untuk kesempatan yang telah diberikan dan semoga artikel ilmiah ini dapat diterima dengan baik.

\section{REFERENSI}

A.A. Anwar Prabu Mangkunegara, (2002), Manajemen Sumber Daya Manusia, Perusahaan, Bandung: PT. Remaja Rosdakarya.

A.M, Sardiman. (2007), Interaksi dan Motivasi Belajar Mengajar. Jakarta, Raja Grafindo Persada

Ahmad Nur Rofi, (2012), Pengaruh Disiplin Kerja dan Pengalaman Kerja terhadap Prestasi Kerja Karyawan pada Departemen Produksi PT. Leo Agung Raya Semarang, Jurnal Ilmu Manajemen dan Akuntansi Terapan, Vol 3 Nomor 1, Mei 2012

Agung Prihantoro, (2012), Peningkatan Kinerja Sumber Daya Manusia Melalui Motivasi, Disiplin, Lingkungan Kerja, Dan Komitmen (Studi Kasus Madrasah Di Lingkungan Yayasan Salafiyah, Kijen Margoyoso, Pati), Sekolah Tinggi Agama Islam Mathali'ul Falah.

Arsyenda, Yoga, (2013), Pengaruh motivasi kerja dan disiplin kerja terhadap kinerja PNS (studi kasus:BAPPEDA kota Malang), Jurnal Ilmiah. Malang, Fakultas ekonomi dan bisnis, Universitas Brawijaya.)

Azwar, S, (2015). Penyusunan Skala Psikologi Edisi 2. Yogyakarta, Pustaka Belajar 
A.A. Anwar Prabu Mangkunegara, (2016), Manajemen Sumber Daya Manusia, Perusahaan. Bandung : PT. Remaja Rosdakarya

B. Uno, Hamzah, (2007), Teori Motivasi dan Pengukurannya, Jakarta:Bumi Aksana)

Elvi Lastriani, (2014), Pengaruh Disiplin Terhadap Kinerja Anggota Pada Satlantas Polresta Pekanbaru Galih Rakawisi, (2014), Pengaruh Motivasi, Kepuasan Kerja Dan Disiplin Kerja Terhadap Kinerja Pegawai (Studi Empiris Pada Satuan Polisi Pamong Praja Kabupaten Karanganyar), http://v2.eprints.ums.ac.id/archive/etd/30339

Husein Umar,.(2013), Metode Penelitian untuk Skripsi dan Tesis, Jakarta: Rajawali

Ilyas, (2001), Manajemen Sumber Daya Manusia, Bumi Aksara, Jakarta.

Ivonne A. S. Sajangbati, (2013), Motivasi Disiplin dan Kepusan Pengaruhnya Terhadap Kinerja Pegawai PT. Pos Indonesia (Persero) Cabang Bitung. https://ejournal.unsrat.ac.id/index.php/emba/article/view/2750

Jentot Tugiyono, (2019), Pengaruh Motivasi Kerja Terhadap Kinerja Karyawan LPK Pramidia Bandung. https://ejournal.poltektedc.ac.id/index.php/tedc/article/view/311

Marwansyah dan Mukaram, (2002), Manajemen Sumber Daya Manusia, Edisi Kedua. Administrasi Negara: Bandung.

Mangkuprawira.S Dan Aida V.Hubeis, (2007), Manajemen Mutu Sumber Daya Manusia. GHALIA INDONESIA.Bogor

M. Holil dan Agus Sriyanto, (2010), Pengaruh Motivasi dan Disiplin Terhadap Kinerja Pegawai Dengan Pemberian Insentif Sebagai Variabel Moderasi (Studi Kasus di Sekretariat Daerah Kabupaten Jayawijaya), Jurnal Keuda Vol. 2 No. 1 ISSN 2477-7838, https://media.neliti.com/media/publications/217591-pengaruh-motivasi-dan-disiplinterhadap.pdf

Natalia Susanto, (2019), Pengaruh Motivasi Kerja, Kepuasan Kerja dan Disiplin Kerja Terhadap Kinerja Karyawan Pada Divisi Penjualan PT. Rembaka, http://publication.petra.ac.id/index.php/manajemen-bisnis/article/view/8153

Nita Nilamsari, (2014), Pengaruh Motivasi Kerja Terhadap Kinerja Karyawan Serta Dampaknya Pada Kualitas Pelayanan Housekeeping Department Di Padma Hotel Bandung. https://123dok.com/document/yr3820jy-pengaruh-motivasi-karyawan-dampaknya-kualitaspelayanan-housekeeping-department.html

Prof. Dr. Ir. Hj. Lubis, Yusniar, Dr. Bambang Hermanto dan Dr. Emron Edison, (2019). Manajemen dan Riset. Bandung: Alfabeta.

Purhantara, Wahyu, (2010), Metode Penelitian Kualitatif Untuk Bisnis, Yogyakarta: Graha Ilmu.

Polancik, G, (2009), Empirical Research Method Poster. Jakarta:

Rivai, (2004, h:444), Manajemen Sumber Daya Manusia Untuk Perusahaan, Jakarta:Grafindo

Stuart Emmel, (2001), Manajemen SDM, Defenisi Disiplin Kerja.

Siagian,Sondang P, (2004), Teori Motivasi Dan Aplikasinya, Bina Aksara Jakarta

Sandy Martha, Muhammad, (2015), Karakteristik Pekerjaan dan Kinerja Dosen Luar Biasa UIN Sunan Gunung Djati Bandung: Komitmen Organisasi Sebagai Variabel Moderating, Tesis di Universitas Widayatama Bandung.

Syahyuti, (2010), Defenisi, Variabel, Indikator dan Pengukuran dalam Ilmu Sosial, Bina Rena Pariwara, Jakarta

Tika H. Moh. Pabundu, (2006), Budaya Organisasi dan Peningkatan Kinerja Perusahaan, Cetakan Pertama, PT. Bhumi Aksara, Jakarta

Tri Hardjono, (2013), Analisis Pengaruh Motivasi, Disiplin Kerja dan Kemampuan Kerja Terhadap PNS, (Studi Empiris pada Kecamatan Mijen Kota Semarang) Jurnal Tesis Program Pascasarjana Magister Manajemen Universitas Dian Nuswantoro Semarang,

Widiyanto, Joko, (2010), SPSS for Windows Untuk Analisis Data Statistik dan Penelitian, Surakarta: BP-FKIP UMS. 